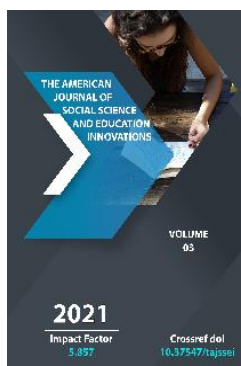

\title{
The Componential Analyse Of English And Uzbek Lullabies Based On Grammatical Signals
}

\author{
Farokhat Sattarbergan Qizi Karimova \\ PhD Student, Urganch State University, Uzbekistan
}

\begin{abstract}
Journal Website:
http://theamericanjour

nals.com/index.php/taj

ssei

Copyright: Original content from this work may be used under the terms of the creative commons attributes 4.0 licence.
\end{abstract}

\section{ABSTRACT}

The article gives data on English and Uzbek lullabies and their componential analyses. The analyze has been done based on the grammatical signals which in both languages. Results show that the components of English and Uzbek languages are similar in terms of possessive, plural, prosody and occasionally derivational contrast. The components of English and Uzbek languages are different in terms of the case, function words and word order.

\section{KEYWORDS}

Lullabies, componential analyze, semantic components, grammatical signals, grammatical form, categories, similarities, differences.

\section{INTRODUCTION}

This study aims to give an account for the subject of componential analysis as it is considered to be an important approach to the study of components. It is clear that the value of componential analysis is the description of particular language, is not affected by the status of the semantic components in universal terms. The componential analyze done in the following article is based on grammatical signals in
English and Uzbek languages in the examples of three types of lullabies including Religious, Healing and Functional. Grammatical signals express grammatical cohesion. General structure or feature of the languages is identified with the help of those signals. Grammatical signals expressing coherence are the elements that are repeatedly used in the language by which differ from lexical elements. For example, grammatical signals 
can be used several times on a page of work. But it cannot be true for lexical units. Otherwise, redundancy occurs in a language.

\section{MATERIAL AND METHODS}

Lullaby samples which were chosen to analyze for our research have been taken from reliable resources such as the books of Okhunjan Safarov. He is a great folklorist and the main collector of Uzbek lullabies. His collections are useful sources for our research work. English lullabies have been taken from different materials including 'Folk lullabies of the world' by Barbara and Michael Cass-Beggs.

While writing this article we applied to several methods inluding method of Description, Comparative method, Component analysis method. With the help of the abovementionted methods we tried to compare the components of the lullabies of the two countries. Component analysis method is based on the grammatical signals that exist in both languages. By using description method we described grammatical signals one by one. Grammatical signals are particularized from both English and Uzbek languages. Their similarities and distinctions are characterized with examples.

\section{RESULT}

The results of analyses show that both languages differ from each other significantly. For example, in English language there is no any derivational suffix in the analyzed parts of sentences. But Uzbek language has some derivational suffixes such as -la. Besides we can see a difference in word order. In English language it is Subject Verb Object, but in Uzbek language it is Subject Object Verb.

\section{DISCUSSION}

Grammatical signals show syntactic connection among words. Hovewer, their number is limited. There are five main signals for Modern English Grammar System and they are the followings. The same signals apply for the current grammar system of the Uzbek language.

Table 1

\begin{tabular}{|c|c|}
\hline English & Uzbek \\
\hline 1. Inflexions & 1. Fleksiya \\
\hline 2. Function words & 2. Yordamchi so'zlar \\
\hline 3. Word order & 3 So'z tartibi \\
\hline
\end{tabular}




\begin{tabular}{|c|c|}
\hline 4 Prosody & 4 Prosodiya yoki intonatsiya \\
\hline 5 Derivational contrast & 5 Derivatsion contrast \\
& \\
\hline
\end{tabular}

Although the general function of these grammatical signals is to express syntactical relations of words, each of which functions a particular special task. They are used to form grammatical categories.

Though the abovementioned five grammatical signals belong to both languages, their usage is distinct from each other. For example, flexion is used in both languages; however, there is a difference in word order. Function words are used more in the English language even though it is considered to be the main signal in both languages.

Flexion - besides being one of the main signals in English and Uzbek languages, is expressed by grammatical morphemes forming grammatical forms of the words.

1) Comparative table of flexion signals is below:

Table 2

\begin{tabular}{|c|c|c|c|}
\hline \multirow{2}{*}{ Languages } & \multicolumn{3}{|c|}{ Flexional signals } \\
\cline { 2 - 4 } & Possessive suffix & Case suffix & Plural suffix \\
\hline English & - & + & + \\
\hline Uzbek & + & + & + \\
\hline
\end{tabular}

Function words. Function words are the words that are independent, without special meaning, help independent phrases to contact with each other in grammatical terms showing the presence of semantic-syntactic relationships among them, and are not used as fragments of speech.
Word order is characterized by the fact that the parts of the sentence are strict or not, they are relevant or irrelevant. [2; 89-95]

We start analyzing English and Uzbek lullabies according to their semantic division on types. The first type is the historical type of lullabies in both languages. 
Table 3

\begin{tabular}{|c|c|}
\hline $\begin{array}{c}\text { Bless this child } \\
\text { Bless this child } \\
\text { Beautiful, meek and mild } \\
\text { May you know all the beauty that there is in this } \\
\text { world } \\
\text { Bless this child } \\
\text { Bless this child }\end{array}$ & $\begin{array}{l}\text { Alla alla! } \\
\text { Alla bolam, alla, solih bolam, alla, } \\
\text { Seni bergan Robbimga hamdu sano, alla! } \\
\text { Alla bolam, alla, mo'min bolam, alla, } \\
\text { Seni bergan Robbimga hamdu sano, alla! } \\
\text { Bo'lgin bog'imning guli, sen Allohimning quli } \\
\text { Sen Muhammad ummati, bo'l dinimning quvvati, }\end{array}$ \\
\hline
\end{tabular}

Table 4 shows the component analyses of historical type lullabies in English and Uzbek languages.

Table 4

\begin{tabular}{|c|c|c|c|c|c|c|c|}
\hline \multirow[t]{3}{*}{ Examples } & \multicolumn{7}{|c|}{ Grammatical signals } \\
\hline & \multicolumn{3}{|c|}{ Inflexions } & \multirow{2}{*}{$\begin{array}{l}\text { Function } \\
\text { words }\end{array}$} & \multirow{2}{*}{$\begin{array}{l}\text { Word } \\
\text { order }\end{array}$} & \multirow[t]{2}{*}{ Prosody } & \multirow{2}{*}{$\begin{array}{l}\text { Derivational } \\
\text { contrast }\end{array}$} \\
\hline & \begin{tabular}{|l} 
posses \\
sive
\end{tabular} & case & plural & & & & \\
\hline English & - & - & - & + & VSO & + & - \\
\hline Uzbek & + & + & - & - & VS & + & - \\
\hline
\end{tabular}

In the given component examples

May you know all the beauty that there is in this world and
Bo'lgin bog'imning guli, sen Allohimning quli

are chosen to compare. The obvious difference lays in Word order as English example starts from Verb followed by Subject 
and object while Uzbek example consists of only Verb and Subject. As for inflexions, the Uzbek language has possessive and case category when English has neither. The suffix '-ning' in 'bog'imning' is a signal showing possessive case and ' $\mathrm{i}$ ' in the word 'guli' and 'quli' is a possessive suffix in the Uzbek language. The plural category cannot be met in both language components.
Function words. In the English phrase 'May you know all the beauty that there is in this world' the word 'all' is stressed like 'Allohimning' in the Uzbek language. Therefore stressed words form prosody in both languages. Not any word has a derivational suffix in both English and Uzbek language.

Table 5

\begin{tabular}{|c|c|}
\hline $\begin{array}{c}\text { I had a belly full of night lights and kisses } \\
\text { I had a belly full of sunshine in your hair } \\
\text { I had a belly full of teddy bears and special } \\
\text { dolls } \\
\begin{array}{c}\text { Come dry my tears. } \\
\text { Corms are aching now }\end{array}\end{array}$ & $\begin{array}{r}\text { Sochin yozib onam yig'lar, alla-yo, alla, } \\
\text { Beli bog'liq otam yig'lar, alla-yo, alla. } \\
\text { Lahat og'zi suvalganda, alla-yo, alla, } \\
\text { Mening vasfim ado bo'Imas, alla-yo, alla. }\end{array}$ \\
Bulbuligo'yo bo'lsam, alla-yo bir alla, \\
G'am qayg'uni xatga olsam, alla-yo bir alla. \\
Azroillar kelganda-yo, alla, \\
Shu xatni unga tutsam-o, alla, \\
Rahmi kelmasmikan-o, alla-yo bir alla. \\
[3; 90]
\end{tabular}

Componential analyses of Healing type is described in Table 6.

Table 6

\begin{tabular}{|c|c|c|c|c|c|}
\hline \multirow{2}{*}{ Examples } & \multicolumn{4}{|c|}{ Grammatical signals } \\
\hline & Inflexions & $\begin{array}{c}\text { Function } \\
\text { words }\end{array}$ & $\begin{array}{c}\text { Word } \\
\text { order }\end{array}$ & Prosody & $\begin{array}{c}\text { Derivational } \\
\text { contrast }\end{array}$ \\
\hline
\end{tabular}




\begin{tabular}{|c|c|c|c|c|c|c|c|}
\hline & $\begin{array}{c}\text { posses } \\
\text { sive }\end{array}$ & case & plural & & & & \\
\hline English & + & - & - & + & SVO & - & + \\
\hline Uzbek & + & + & - & + & ovs & - & + \\
\hline
\end{tabular}

\section{I had a belly full of sunshine in your hair}

and Sochin yozib onam yig'lar, alla-yo, alla

are comparable parts of English and Uzbek languages. These examples are of healing type of lullabies. Thus we can see the words denoting 'ache', 'tears' in English whilst 'yig'i', 'vasf', 'g'am-qayg'u', and 'azroil' in Uzbek language. The most noticeable components here consisted of the same lexical units: the 'hair' and 'tear' in English and 'soch' and 'yig'i' in Uzbek languages. This can be a similar feature of two languages, especially in the same type.

Regarding the componential analyse of them, almost the same grammatical signals comprise the verse excluding case category in the
English language. The rest makes no difference from each other. For example, inflexion exists in both languages in the form of possessive pronoun 'your' in English and possessive suffix '- $m$ ' in 'onam' in the Uzbek language. '-in' is the abbreviated form of suffix '-ni' of which the suffix of case (Tushum kelishigi) is used in the word 'sochin'. The usage of function words can be seen in the examples of the preposition 'of' and 'in' in English language and '-yo' in the Uzbek language. Word order follows the correct usage in English but in the Uzbek language, the reverse happens. 'Sunshine', a combination of two words 'sun' and 'shine', is a good example of derivational contrast. From the noun, 'yig'i' by adding verb suffix '-la' forms new verb 'yig'lamoq' in Uzbek language.

Table 7 
Dance to your Daddy, my little laddie,

Dance to your Daddy, my little lamb.

When thou art a man and fit to take a wife.

Thou shalt choose a maid and love her allyour life.

She shalt be your lassie, thou shalt be her man, Dance to your Daddy, my little lamb.

$[4 ; 28]$
To'yingda qo'ylar so'yay-o, alla-yo alla,

Momosi quyruq yesin, alla-yo alla.

Yuzingdan to'yib o'pay-o, alla-yo alla,

Berganing buyruq bo’lsin, alla-yo alla.

Ota-onasi ko'zmunchog'i, alla-yo alla,

Sendan kelar gul isi, alla-yo alla.

Ota-onasin qo'zichog'i, alla-yo alla,

Momosining erkatoy qizi, alla-yo alla.

$[5 ; 54]$

Table 8 shows the componential analyses of functional type in English and Uzbek languages.

Table 8

\begin{tabular}{|c|c|c|c|c|c|c|c|}
\hline \multirow{2}{*}{ Examples } & \multicolumn{7}{|c|}{ Grammatical signals } \\
\hline & \multicolumn{2}{|c|}{ Inflexions } & \multirow{2}{*}{$\begin{array}{c}\text { Function } \\
\text { words }\end{array}$} & $\begin{array}{c}\text { Word } \\
\text { order }\end{array}$ & Prosody & $\begin{array}{c}\text { Derivational } \\
\text { contrast }\end{array}$ \\
\cline { 2 - 8 } & $\begin{array}{c}\text { posses } \\
\text { sive }\end{array}$ & case & plural & & & \\
\hline English & + & - & - & + & vo & + & + \\
\hline Uzbek & + & + & - & + & $\mathrm{S}$ & + & - \\
\hline
\end{tabular}

The components of phrases Dance to your Daddy, my little lamb and Ota-onasin qo'zichog'i, alla-yo alla are being compared. Both languages have possessive elements 'your' and 'my' in English and -sin in the Uzbek language. This suffix is the abbreviated form of - si which is possessive suffix and ning which shows possessive case. 
Components do not have plurality forms but function words such as the preposition 'to' in English language and '-yo' in the Uzbek language. Word order is completely different from other lullaby components because English text has only verb and object while Uzbek has the only subject. Both components have stressed words, 'lamb' in the English language and 'qo'zichog'i' in the Uzbek language. Here we can see the usage of the same lexical units and both of them are stressed. No derivation suffix is met among components.

The findings of our research are quite convincing and thus the following conclusions can be drawn:

\section{CONCLUSIONS}

The components of English and Uzbek languages are similar in terms of possessive, plural, prosody and occasionally derivational contrast. Both languages have possessive elements in lullaby texts either in possessive pronoun or possessive suffix. Although derivational suffix is rare in lullaby texts, some examples were observed. Plural suffixes can be met in neither language in the selected components.

The components of English and Uzbek languages are different in terms of the case, function words and word order. Though function words are active in the forms of prepositions, conjunctions and auxiliary verbs, they are not met equally in two languages. The same applies to the case. It is active in the Uzbek language while the English language rarely uses it. Word order also distinguishes from each other significantly.
1. Macmillan English Dictionary for AdvancedLearners.China.:

Macmillan,2007.

2. J.B.Bo'ronov. Ingliz va o'zbek tillari qiyosiy grammatikasi. O'qituvchi. Toshkent 1973.

3. O. Safarov, El suyarim,alla. "O'zbekiston" 2009.

4. Barbara and Michael Cass-Beggs. Oak publications. London/New York/Paris/Sydney/Copenhagen/Madri d. Folk lullabies of the world. 2014.(p127)

5. Ohunjon Safarov.O'zbek xalq allalari. ‘Alla-yo alla”O'qituvchi'1999.

6. Ermetova J.I. Comparative analysis of the use of punctuation marks dash and hyphen in English and Russian, Urgench, Actual problems of modern science education and training in the region.article 2018.

\section{REFERENCES}

